and more dissatisfied. These observations are put forward with little to substantiate them experimentally, and the author pleads for a competent analysis of the relationship between work and Keisure. If the theory that there is a vicious and a virtuous circle in the use of energy be true, a different attitude in industry may have to be developed, and par. ticularly towards the young worker.

\section{Royal Photographic Society's Annual Exhibition}

THE Royal Photographic Society's ninety-fourth annual exhibition of photgsraphy will be opened in the Society's House at 16 Princes Gate, London, S.W.7, on Septembor 8. For this year's exhibition, 5,300 entries were received, of which 863 have been accepted. Lingitations of space in the Society's House make it necessary to divide the exhibition into the following two parts: Part 1 : pictorial, colour and stereoscopic (prints and transparencies), September 9 to October 2, inclusive; Part 2 : scientific, Nature, record and technical (prints and transparencies), October 8 to 26 , inclusive.

\section{Institute of Metals: Autumn Meeting in Paris}

By invitation of the Société Française de Métallurgie and the French Non-Ferrous Metal Industries, the Autumn Meeting of the Institute of Metals will be held this year in Paris during October 3-8, followed by tours outside the Paris area. At the same time, and in the sayne building, the annual meeting of the Société Frghçaise de Métallurgie will be held. Care will be taken that the non-ferrous sessions of the two socidties do not clash. The meeting of the Société Française de Métallurgie will open at 10 a.m. on October 3, when Dr. R. Seligman will deliver an address in French. Members of the Institute of Metals are invited to be present. This is the first meeting of the Institute to be held outside the British Isles since 1936.

The programme includes the twenty-seventh Autumn Lecture, to be delivered by Prof. Georges Chaudron, on "Recent French Work in the Field of Light Alloys". The works, etc., to be visited include the laboratories of the Centre Nationale de la Recherche Scientifique, Vitry ; Le Magnésium Industriel, Levallois; Manufacture d'Armes de Paris (MAP), St. Denis ; Laboratoires du Centre National de la Recherche Scientifique, Bellevue; Cie. FacelMetallon, Colombes; the Michelin Train; Centre Technique de l'Aluminium, Paris; Régie Nationale des Usines Renault, Billancourt; Etablissements JAPY, Arcueil ; Société des Trèfileries et Laminoirs du Hâvre, Cableries de Saint-Maurice ; and Fonderies Montupet, Creil.

\section{Symposium on Electronics}

THE Electronics Section of the Scientific Instrument Manufacturers' Association is arranging a symposium to be held gt the Examination Hall, Queen's Square, London, W.C.1, during November $2-4$. A separate hall has been secured in the building so that a comprelensive display of the latest types of British sciegtific and electronic instruments can be demonstrated during the period of the symposium. The topics for discussion include electronic instrumentation in atomic research, electronic amplifiers, magnetic amplifiers, recent improvements in electronic measuring techniques, measurement of transient phenomena, an industrial electronic servo. mechanism, and co-operative research at the British
Scientific Instrument Research Association. Entrance to the symposium itself will be by ticket (covering also the exhibition), obtainable on application to the Secretary, Scientific Instrument Manufacturers Association, 17 Princes Gate, London, S.W.7.

\section{Symposium on Metallurgical Applications of the Electron Microscope}

THE Institute of Metals is organising an all-day Symposium on "Metallurgical Applications of the Electron Microscope", which will be held at the Royal Institution, London, S.W.1, on November 16 , commencing at 10 a h. The following societies are associated with the Institute in arranging this meeting: Chonical Society; Faraday Society ; Electron Microscope Group of the Institute of Physics; Institution of Electrical Engineers; Iron and Steel Institute; Physical Society; and Royal Microscopical Society.

\section{Aslib Guides}

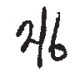

AsLIB is issuing a series of "Guides" intended to form cumulatively a new edition of the Aslib Directory. No. 3, entitled "Beverages and Foods" (Aslib. Pp. iii +56. 12s. 6d. net. 10s. to members), is in three sections. ofe fiondeals with libraries and loan services and withe Department of Scientific and Industia Regrch. The second details the organisations Wredt Britain which are the main source of information on beverages and food omitting peferences to commercial firms. The third section lists publications in three classes : periodicals printing abstracts or lists of references; directories, annuals and yearbooks ; and periodicals in general. Separate subject indexes to the first two and to the third section are provided, and the Guide is printed in a form suitable for inclusion in a loose-leaf binder.

\section{Announcements}

THE first Douglas Lea Memorial Lecture of the Hospital Physicists' Association will be given, on September 16, at the British Institute of Radiology, 32 Yelbeck Street, London, W.1, when Dr. F. G. Spear, of Cambridge, will speak on "The Physicist and his Colleagues"

UNESco proposes to publish later in the year a "Manual gn the International Exchange of Publications". It is intended to publish as an annex to this Manual a classified list of institutions, including libraries, universities, scientific institutions, learned societies, etc., throughout the world, which are willing to exchange either their own publications or other publications which they have regularly at their disposal. Further information can be obtained from Unesco Clearing Hoyse for Publications, 19 Avenue Kléber, Paris, $16 \mathrm{e}$

Messrs. H. J. Elliotr, Ltd., Treforest Trading Estate, Gam., have submitted a specimen of their "E-MIZ "Companion" pocket thermometer, 7s.6d. This thermometer is graduated from $35^{\circ}$ to $220^{\circ} \mathrm{F}$. by $2^{\circ}$ marks, and is fred at one end to a bracket sliding in a slot in a heat plastic case some 5 in. long. The case has a convenient metal pocket-clip.

Erratum Dr. Forrest Fulton states that, in his communication entitled "Growth-Cycle of Influenza Virus", In Nature of July 30, p. 189, the figure 5120 whick appears three times in the third column of Table 1 should be, on each occasion, 512 . 